\title{
NASA privacy case goes to highest court
}

\section{The US Supreme Court will rule on sweeping background checks on scientists at the Jet Propulsion Laboratory.}

\section{BY EUGENIE SAMUEL REICH}

$\mathrm{F}$

Ior Robert Nelson, a planetary scientist who led the science team for NASA's Deep

Space 1 flyby of Comet Borelly in 2001, the happiest day of the past three years came when a respected civil-rights law firm agreed to take on his lawsuit against the US space agency.

This week, Nelson $v$. NASA reaches the US Supreme Court, which will have to decide whether to uphold a lower court's preliminary injunction halting extensive investigations into the personal lives of employees at the Jet Propulsion Laboratory (JPL) in Pasadena, California. The case may have far-reaching implications for the privacy rights of scientists receiving US government funds.

"Yes, the investigators even want to ask about who we've slept with," Nelson told a press conference convened last week by the Union of Concerned Scientists (UCS), an advocacy group in Cambridge, Massachusetts, which has filed a brief with the court in support of Nelson and 27 co-plaintiffs.

The background investigations stem from Homeland Security Presidential Directive 12, introduced in 2004 during the administration of George W. Bush. Its purpose was to institute a standard identification badge to gain access to federal facilities, although the procedure needed to obtain the badge was left up to individual agencies. NASA required its contractors' employees to sign a waiver permitting investigators to collect "any adverse information" from anyone they liked, including information related to "abuse of alcohol and/or drugs", "mental or emotional stability", "general behavior or conduct", or "other matters".

Most of the JPL's 5,000 or so workers are employed by the Pasadena-based California Institute of Technology - which runs the JPL under contract with NASA - and are therefore subject to the wide-ranging inquiries required by NASA's reading of the presidential directive. In August 2007, under threat of losing their jobs, Nelson and the 27 other JPL employees sued rather than submit to the extra investigations. On 5 October, the day of the JPL's deadline requiring them to sign the waiver or be dismissed, an appeals court issued a preliminary injunction stating that the investigations infringed a constitutional right to privacy because they were not narrowly tailored to national security interests. Two subsequent rulings by the same court set the injunction on course to become permanent, but in November 2009 the US Department of Justice appealed to the Supreme Court, which will hear the case on Tuesday and could issue an opinion any time after that. The current Supreme Court has heard few cases balancing privacy rights with national security, making it unclear which way it will rule.

The US Department of Justice did not ${ }^{\frac{5}{2}}$ respond to a request for comment. In its brief to the Supreme Court, it describes the investigations as "basic background checks" that are needed to ensure the safety and security of federal facilities. It also notes that the US Privacy Act should prevent the personal information that is collected from ever becoming public.

In a brief supporting the scientists, the American Astronomical Society (AAS) in Washington DC argues that the case could set a precedent that would allow similarly openended investigations of any scientist who needs access to federal facilities or who is applying for federal grant money. "We were concerned that this was impacting some people's ability to do research," says AAS president Debra Elmegreen, an astronomer at Vassar College in Poughkeepsie, New York. Kurt Gottfried, an emeritus professor of physics at Cornell University and a UCS board member, told the press conference that the Obama administration was taking essentially the same approach to national security as that of Bush. "This policy $\rightarrow$ NATURE.COM Why are Saturn's rings so icy? go.nature.com/qwpkxw will set a harmful precedent. It will make it much more difficult to retain and attract top scientific staff," he said. - 